\title{
Immune Checkpoint Blockade in Hepatocellular Carcinoma: 2017 Update
}

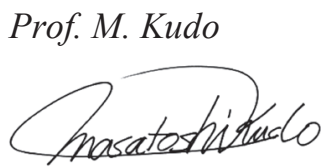

Editor Liver Cancer

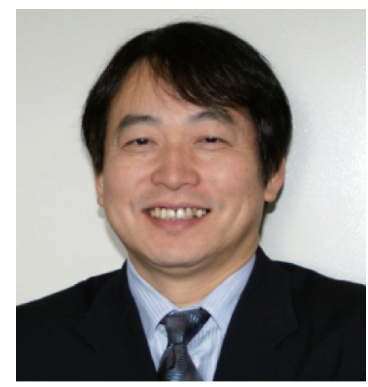

\section{Introduction}

The immune checkpoint molecule programmed cell death 1 (PD-1) was discovered in 1992 by Professor Tasuku Honjo and his research team at Kyoto University [1]. They later discovered that PD-1 is involved in immunosuppression and is a receptor that acts as a "brake" for the immune response in knockout mice. In 2000, a joint research project between the Honjo group at Kyoto University and the Genetics Institute together with Harvard University discovered the ligands of PD-1 (PD-L1 and PD-L2) [2-5]. In 2002, Iwai et al. [6] found that enhancing immune activation by inhibiting the binding of PD-1 to its ligands in mouse models markedly enhanced antitumor activity. In 2005, Ono Pharmaceutical and the American company Medarex took note of these findings and developed nivolumab, a human anti-PD-1 antibody. That same year, the U.S. Food and Drug Administration (FDA) recognized nivolumab as an investigational new drug, thereby enabling clinical trials to be started in the United States. In 2009, Bristol-Myers Squibb and Ono Pharmaceutical (BMS/ONO) began joint clinical trials of nivolumab. The results of clinical trials in patients with melanoma led to the approval of an anti-PD-1 antibody for the treatment of melanoma in Japan in July 2014 , before any other country in the world. Nivolumab has also been evaluated in a series of clinical trials for non-small cell lung cancer and renal cell carcinoma and has yielded favorable outcomes.

In 1995, Dr. James Allison of the University of Texas discovered that another molecule, called cytotoxic T-lymphocyte-associated antigen (CTLA-4) [7], serves as an indicator of immune cell suppression [7]. In 1996, his team showed that tumors disappeared in mice treated with an antibody that inhibits the function of CTLA-4 [8]. CTLA-4 is also an immune checkpoint molecule. Bristol-Myers developed an anti-CTLA-4 antibody called ipilimumab, which was approved for the treatment of melanoma in the United States in March 2011 and in Europe in July 2011 [9]. It was later approved in Japan in July 2015.

When cancer cells develop, antigen-presenting cells (APCs) recognize tumor-associated antigens (TAAs), triggering in the lymph nodes the activation of immature $\mathrm{T}$ cells that will become CD8-positive T cells (the priming phase). Once activated, the T cells travel throughout the bloodstream and reach the tumor site. There, they attempt to attack tumor cells by 


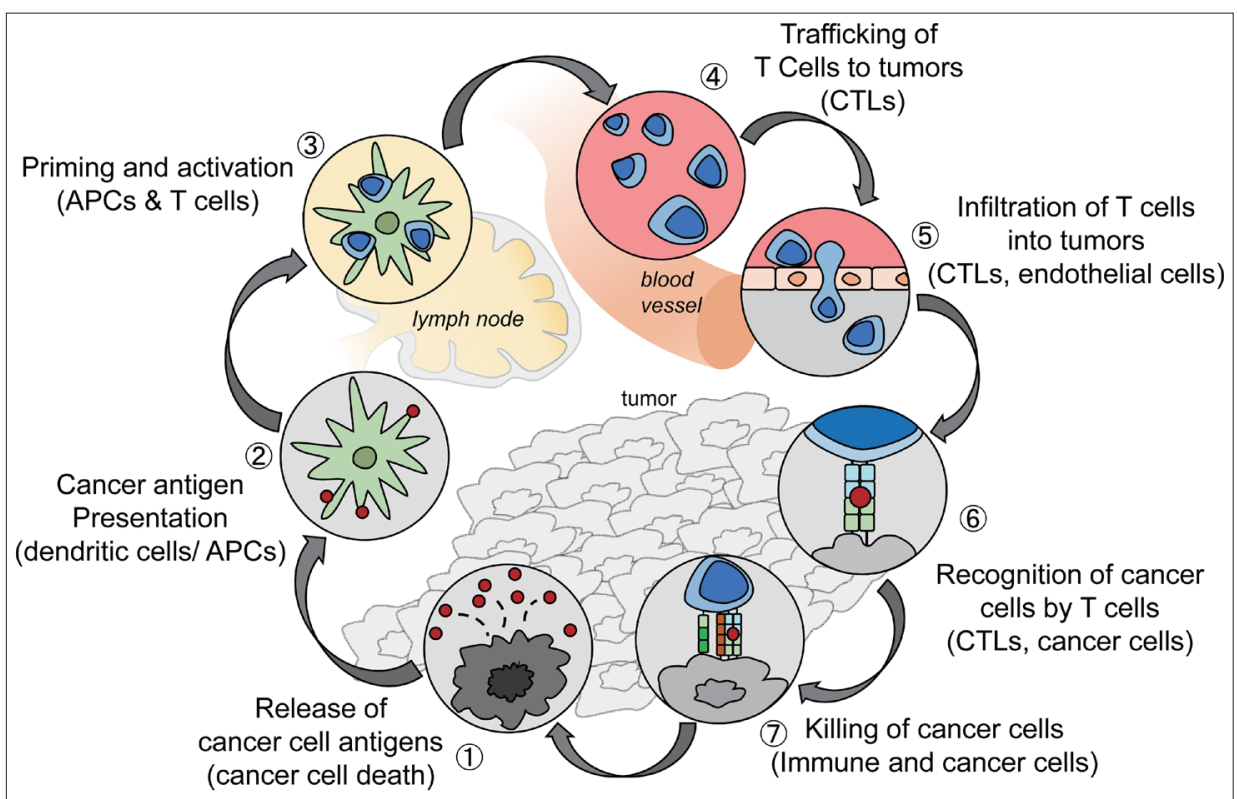

Fig. 1. The cancer-immunity cycle. The generation of immunity to cancer is a cyclic process that leads to an accumulation of immune-stimulatory factors. This cycle can be divided into seven major steps, starting with the release of antigens from cancer cells and ending with the killing of cancer cells. CTLs=cytotoxic T lymphocytes. Reproduced with permission from Chen DS, et al. [10]

releasing molecules such as perforin and granzymes (the effector phase) (fig 1) [10]. Moreover, recognition of TAAs by T cell receptors (TCR) triggers the release of interferon gamma (IFN- $\gamma$ ) and other cytokines by CD8-positive T cells in an attempt to attack the cancer. However, tumor cells protect themselves by expressing IFN- $\gamma$ induced PD-L1 or PD-L2, which binds to PD-1. When this happens, PD-1/PD-L1 binding attenuate the antitumor immune response, thereby weakening the attacking power of the T cells. This is called immune escape or immune tolerance (fig. 2). The anti-PD-1 antibody blocks PD-1 on activated T cells from binding to PD-L1 or PD-L2 on APCs or tumor cells. This removes the "brake" on the immune system and restores the ability of $\mathrm{T}$ cells to attack tumor cells (fig. 3). Unlike conventional chemotherapy or molecular targeted therapy, anti-PD-1 antibody achieves its antitumor effect by restoring the original potential of the natural human immune system as a powerful and precise weapon against cancer cells [11-22]. Antibodies against PD-L1 expression in the cancer tissue are believed to have a similar effect [23]. The recognition of "immuno-oncology" using immune checkpoint inhibitors was considered the "Breakthrough of the Year" by the American journal Science in 2013, and immuno-oncology has been widely publicized. PD-L1 also serves as a biomarker that predicts the response to anti-PD-1 antibody [24]. In addition, Kupffer-phase Sonazoid contrast-enhanced ultrasonography is an effective imaging method for predicting the response to treatment with anti-PD-1 antibody [25].

\section{Development of Immune Checkpoint Inhibitors for Hepatocellular Carcinoma (HCC)}

Promising results from an interim analysis of a phase I/II trial of the anti-PD-1 antibody nivolumab (CheckMate-040 trial dose-escalation cohort) were presented at the 2015 American Society of Clinical Oncology (ASCO) Annual Meeting held in Chicago [26, 27]. This 


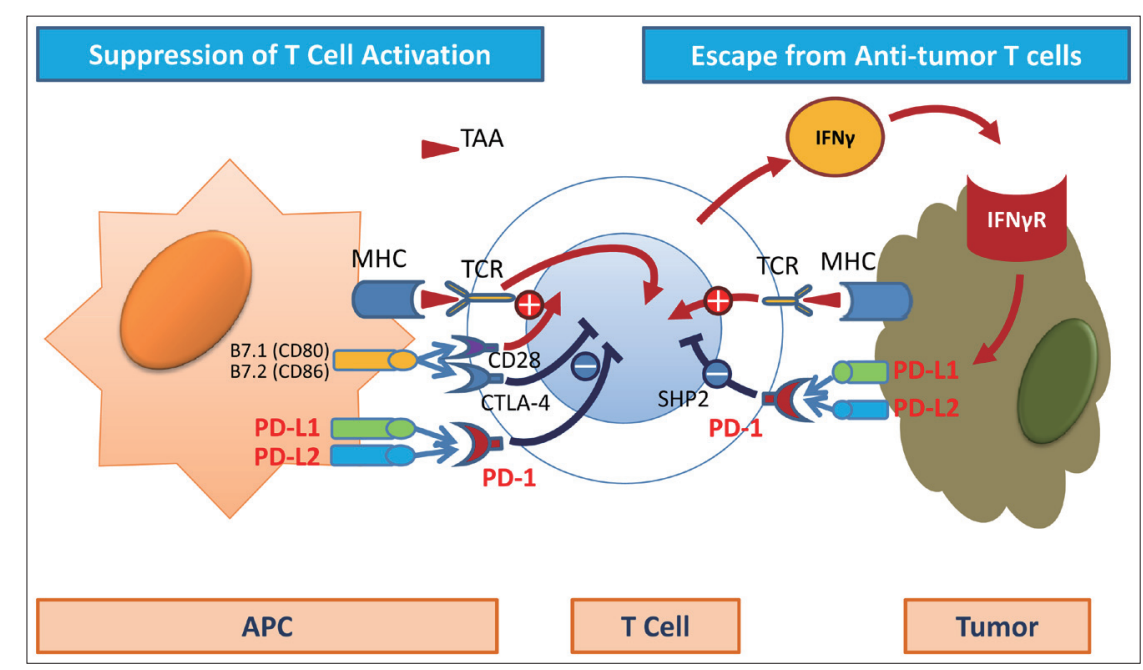

Fig. 2. Immune checkpoint molecule: PD-1, PD-L1, CTLA-4. Immune checkpoint molecules such as PD-1, PD-L1, and CTLA-4 play an important role in the immune escape of cancer cells from activated CD8positive T cells. $\mathrm{MHC}=$ major histocompatibility complex; IFN $\gamma \mathrm{R}=$ interferon gamma receptor.

dose-escalation study demonstrated the safety of nivolumab at doses of $3 \mathrm{mg} / \mathrm{kg}$ and $10 \mathrm{mg} /$ $\mathrm{kg}$ in HCC patients with hepatitis C virus (HCV) infection, patients with hepatitis B virus (HBV) infection, and uninfected patients. The interim results of the dose-escalation study also demonstrated the efficacy of nivolumab at doses ranging from 0.1 to $10 \mathrm{mg} / \mathrm{kg}$. Of the 47 patients included in the study, $33(70 \%)$ had extrahepatic metastasis, $6(13 \%)$ had vascular invasion, and $32(68 \%)$ had previously been treated with sorafenib, i.e., the study population had relatively advanced cancer. Patients were treated with anti-PD-1 antibody, and an interim analysis was performed on March 12, 2015. At that point, 17 patients were still receiving treatment and 30 had completed or discontinued treatment. The reasons for discontinuation were disease progression in 26 patients, complete response (CR) in two patients, and adverse events in two patients. The adverse events leading to discontinuation were increased bilirubin $(n=1)$ and an event unrelated to the study drug $(n=1)$. The only grade 4 event (graded using the Common Terminology Criteria for Adverse Events) was increased lipase, and the only grade 3 events were elevated aspartate aminotransferase (AST) levels in five patients (11\%) and elevated alanine aminotransferase (ALT) levels in four patients (9\%). No serious liver dysfunction or autoimmune disease was reported.

The response rate was $19 \%(n=8)$, including the two CRs $(5 \%)$. The disease control rate (DCR) was also very favorable: $67 \%$ of patients $(n=28)$ maintained stable disease (SD) or better, whereas only $33 \%(n=14)$ developed progressive disease (PD).

Waterfall plots showed that the tumor size decreased to some extent in all cohorts (i.e., uninfected, HBV-infected, and HCV-infected HCC patients). The durability of treatment responses is particularly noteworthy. The two patients who had a CR achieved it within 3 months and maintained it for 18 months. Another patient who showed a partial response (PR) (almost a CR in fact) showed SD at approximately 11 months while the PR occurred at approximately 13 months. A durable response was achieved in all patients with a PR or SD, and no patient developed PD because of resistance. In summary, treatment of liver cancer with anti-PD-1 antibody yielded a durable response comparable to that achieved in other types of cancer. This property is highly characteristic of immune checkpoint inhibitors and merits attention. The two patients who had a CR achieved it within 3 months and maintained the response for 18 months or longer, even after discontinuing the anti-PD- 1 antibody a few months after the 


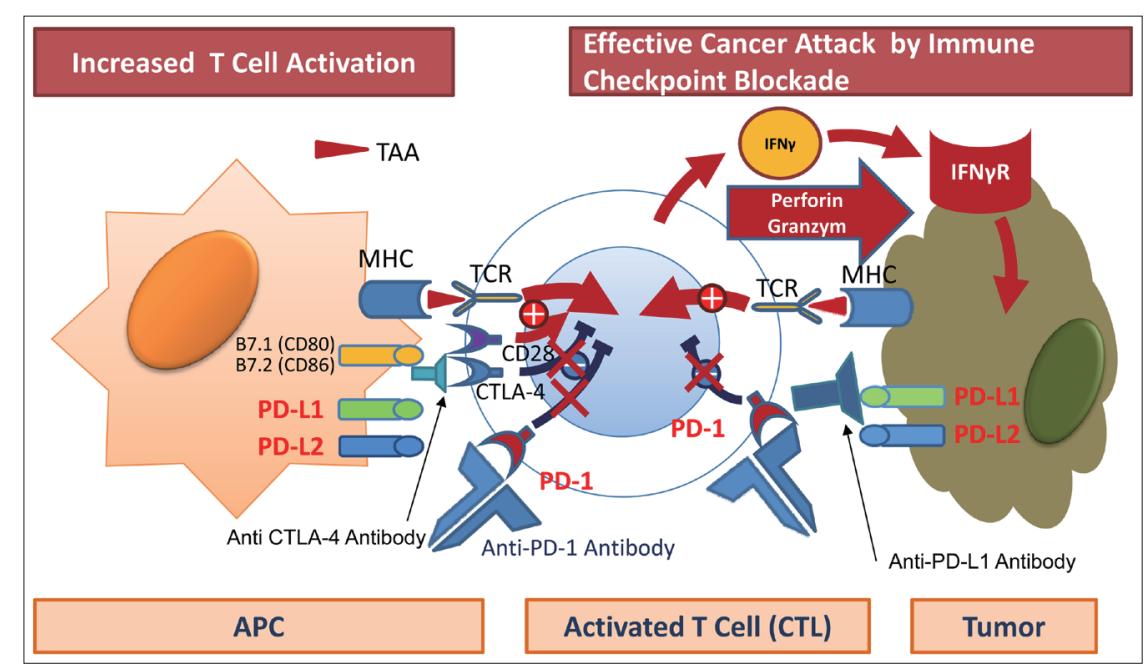

Fig. 3. Immune checkpoint blockade: anti-PD-1, anti-PD-L1, and anti CTLA-4 antibody. Anti-PD-1, antiPD-L1, and anti-CTLA-4 antibodies restore cytotoxic T cell activity, resulting in tumor attack by perforin and granzyme.

CR. Almost all patients who showed a PR achieved it within 3 months of treatment. One of the cases presented at ASCO 2015 was a patient with countless bilobar HCCs, all of which resolved completely after 6 weeks; this was accompanied by a decrease in alpha-fetoprotein from 21,000 to $283 \mathrm{ng} / \mathrm{ml}$. Another patient showed a decrease in tumor size from $10 \mathrm{~cm}$ to about $2 \mathrm{~cm}$ after 48 weeks, which demonstrates the durability of the response. The overall 12 -month survival rate was a favorable $62 \%$, which is a very promising outcome considering the unfavorable tumor characteristics of the study population.

The interim results of this trial can be summarized in three points: First, monotherapy with the anti-PD-1 antibody nivolumab has a favorable safety profile for HCC that is comparable with its safety profile for the treatment of other types of cancer. Second, nivolumab can be used safely in patients infected with HBV or HCV. Third, immunotherapy yields both a very high response rate and a durable response. This long-lasting effect was observed at all dose levels and in all cohorts (uninfected, HBV-infected, and HCV-infected).

The team conducting this phase I/II trial designed an expansion study using a fixed dose of $3 \mathrm{mg} / \mathrm{kg}$ of nivolumab in three cohorts as follows: patients with no HBV or HCV infection who were sorafenib-naïve $(n=50)$ or who had developed PD after treatment with sorafenib $(\mathrm{n}=50)$; HCV-infected patients $(\mathrm{n}=50)$; and HBV-infected patients $(\mathrm{n}=50)$. The results of the expansion study and the final results from the dose-escalation study were presented at ASCO 2016.

\section{Clinical Trials in Progress}

According to the results presented at ASCO 2016, 35 of the 214 patients (16\%) in the expansion cohort (CheckMate-040 cohort 2) had a tumor response [28] (table 1). The response rate was $20 \%$ for uninfected sorafenib-naïve or sorafenib-intolerant HCC patients, $19 \%$ for uninfected sorafenib-treated patients with PD, 14\% for HCV-infected patients, and $12 \%$ for HBV-infected patients. The 9-month survival rate was a favorable 70.8\%. Grade 3-4 adverse events of elevated AST and ALT levels were observed in this expansion cohort at low 
Table 1. CheckMate 040 dose-expansion cohort $(n=214)$ investigator-assessed best overall response (RECIST v1.1)

\begin{tabular}{llllll}
\hline & $\begin{array}{l}\text { Uninfected: } \\
\text { sorafenib naïve } \\
\text { intolerant } \\
(\mathrm{n}=54)\end{array}$ & $\begin{array}{l}\text { Uninfected: } \\
\text { sorafenib } \\
\text { progressors } \\
(\mathrm{n}=58)\end{array}$ & $\begin{array}{l}\text { HCV } \\
(\mathrm{n}=51)\end{array}$ & $\begin{array}{l}\text { HBV } \\
(\mathrm{n}=51)\end{array}$ & $\begin{array}{l}\text { Total } \\
(\mathrm{n}=214)\end{array}$ \\
\hline $\begin{array}{l}11(19) \\
\mathrm{n}(\%)\end{array}$ & $2(3)$ & $7(14)$ & $6(12)$ & $35(16)$ \\
$\mathrm{CR}$ & 0 & 0 & 0 & $2(1)$ \\
PR & $11(20)$ & $9(16)$ & $7(14)$ & $6(12)$ & $33(15)$ \\
SD & $32(59)$ & $27(47)$ & $29(57)$ & $23(45)$ & $111(52)$ \\
PD & $11(20)$ & $18(31)$ & $12(24)$ & $22(43)$ & $63(29)$ \\
Not evaluable & 0 & $2(3)$ & $3(6)$ & 0 & $5(2)$ \\
\hline
\end{tabular}

RECIST=response evaluation criteria in solid tumors. Reproduced with permission from Sangro B, et al. [28]

Table 2. CheckMate 040 dose-expansion cohort $(n=214)$ treatment-related adverse events (TRAEs)

\begin{tabular}{|c|c|c|c|c|c|c|c|c|}
\hline & \multicolumn{2}{|c|}{$\begin{array}{l}\text { Uninfected } \\
(n=112)\end{array}$} & \multicolumn{2}{|l|}{$\begin{array}{l}\mathrm{HCV} \\
(\mathrm{n}=51)\end{array}$} & \multicolumn{2}{|l|}{$\begin{array}{l}\text { HBV } \\
(n=51)\end{array}$} & \multicolumn{2}{|c|}{$\begin{array}{l}\text { Total } \\
(n=214)\end{array}$} \\
\hline & $\begin{array}{l}\text { Any } \\
\text { grade }\end{array}$ & $\begin{array}{l}\text { Grade } \\
3-4\end{array}$ & $\begin{array}{l}\text { Any } \\
\text { grade }\end{array}$ & $\begin{array}{l}\text { Grade } \\
3-4\end{array}$ & $\begin{array}{l}\text { Any } \\
\text { grade }\end{array}$ & $\begin{array}{l}\text { Grade } \\
3-4\end{array}$ & $\begin{array}{l}\text { Any } \\
\text { grade }\end{array}$ & $\begin{array}{l}\text { Grade } \\
3-4\end{array}$ \\
\hline $\begin{array}{l}\text { Patients with any TRAE, } n \\
(\%)\end{array}$ & $72(64)$ & $21(19)$ & $37(73)$ & $15(29)$ & $30(59)$ & $3(6)$ & $139(65)$ & $39(18)$ \\
\hline \multicolumn{9}{|c|}{ Symptomatic TRAEs reported in $>4 \%$ of all patients } \\
\hline Fatigue & $31(28)$ & $2(2)$ & $7(14)$ & 0 & $7(14)$ & 0 & $45(21)$ & $2(1)$ \\
\hline Pruritus & $11(10)$ & 0 & $11(22)$ & 0 & $11(22)$ & 0 & $33(15)$ & 0 \\
\hline Rash & $12(11)$ & $1(1)$ & $8(16)$ & 0 & $6(12)$ & 0 & $26(12)$ & $1(0.5)$ \\
\hline Diarrhea & $16(14)$ & $2(2)$ & $3(6)$ & 0 & $1(2)$ & $1(2)$ & $20(9)$ & $3(1)$ \\
\hline Nausea & $8(7)$ & 0 & $6(12)$ & 0 & 0 & 0 & $14(7)$ & 0 \\
\hline Decreased appetite & $5(5)$ & 0 & $2(4)$ & 0 & $3(6)$ & 0 & $10(5)$ & 0 \\
\hline Dry mouth & $5(4)$ & 0 & $1(2)$ & 0 & $2(4)$ & 0 & $8(4)$ & 0 \\
\hline \multicolumn{9}{|c|}{ Laboratory-value TRAEs reported in $>4 \%$ of all patients } \\
\hline ALT increased & $6(5)$ & $2(2)$ & $7(14)$ & $4(8)$ & $2(4)$ & 0 & $15(7)$ & $6(3)$ \\
\hline AST increased & $7(6)$ & $3(3)$ & $6(12)$ & $6(12)$ & 0 & 0 & $13(6)$ & $9(4)$ \\
\hline Platelet count decreased & $4(4)$ & $1(1)$ & $3(6)$ & $2(4)$ & $5(10)$ & $1(2)$ & $8(4)$ & $3(1)$ \\
\hline Anemia & $2(2)$ & 0 & $3(6)$ & $1(2)$ & $3(6)$ & 0 & $8(4)$ & $1(0.5)$ \\
\hline
\end{tabular}

Reproduced with permission from Sangro B, et al. [28]

rates of $6 \%(13 / 139)$ and $7 \%(15 / 139)$, respectively (table 2$)$. Considering that $66 \%$ of the 214 patients had been previously treated with sorafenib, and a high percentage of patients had advanced cancer, a 9-month survival rate of $70.8 \%$ is an excellent result (tables 3,4 ).

The results of additional analysis of the dose-escalation cohort of 48 patients (CheckMate-040 cohort 1) showed a tumor response in seven patients (15\%); the response rate was $13 \%$ in the uninfected group, $30 \%$ in the HCV-infected group, and $7 \%$ in the HBV-infected group [29] (tables 5-7).

The team conducting this phase I/II trial in addition to cohort 1 and 2 , a randomized controlled study comparing nivolumab with sorafenib (cohort 3), a study of combination therapy 
Table 3. CheckMate 040 dose-expansion cohort $(n=214)$ baseline patient characteristics and prior treatment history

\begin{tabular}{|c|c|c|c|c|c|}
\hline & $\begin{array}{l}\text { Uninfected: } \\
\text { sorafenib naïve/ } \\
\text { intolerant } \\
(n=54)\end{array}$ & $\begin{array}{l}\text { Uninfected: } \\
\text { sorafenib } \\
\text { progressors } \\
(n=58)\end{array}$ & $\begin{array}{l}\text { HCV } \\
(n=51)\end{array}$ & $\begin{array}{l}\text { HBV } \\
(n=51)\end{array}$ & $\begin{array}{l}\text { Total } \\
(n=214)\end{array}$ \\
\hline Median age (range), years & $66(20-83)$ & $65(19-80)$ & $65(53-81)$ & $55(22-81)$ & $64(19-83)$ \\
\hline Male, n (\%) & $46(85)$ & $43(74)$ & $43(84)$ & $39(77)$ & $171(80)$ \\
\hline \multicolumn{6}{|l|}{ Ethnicity, n (\%) } \\
\hline White & $36(67)$ & $35(60)$ & 30 (59) & $4(8)$ & 105 (49) \\
\hline Black/African American & $1(2)$ & $1(2)$ & $2(4)$ & $2(4)$ & $6(3)$ \\
\hline Asian & $16(30)$ & $22(38)$ & $18(35)$ & $45(88)$ & $101(47)$ \\
\hline Other & $1(2)$ & 0 & $1(2)$ & 0 & $2(1)$ \\
\hline $\begin{array}{l}\text { Extrahepatic metastases, } \\
\mathrm{n}(\%)\end{array}$ & $42(78)$ & $43(74)$ & 30 (59) & $46(90)$ & $161(75)$ \\
\hline Vascular invasion, n (\%) & $1(2)$ & $3(5)$ & $5(10)$ & $6(12)$ & $15(7)$ \\
\hline \multicolumn{6}{|l|}{ Child-Pugh score, n (\%) } \\
\hline 5 & $41(76)$ & $38(66)$ & $27(53)$ & $44(86)$ & $150(70)$ \\
\hline 6 & $12(22)$ & $20(34)$ & $21(41)$ & $7(14)$ & $60(28)$ \\
\hline 7 & $1(2)$ & 0 & $2(4)$ & 0 & $3(1)$ \\
\hline 9 & 0 & 0 & $1(2)$ & 0 & $1(0.5)$ \\
\hline $\begin{array}{l}\alpha \text {-Fetoprotein }>200 \mu \mathrm{g} / \mathrm{L}, \\
\mathrm{n}(\%)\end{array}$ & $15(28)$ & $26(45)$ & $18(35)$ & $27(53)$ & $86(40)$ \\
\hline \multicolumn{6}{|c|}{ Prior treatment type, n (\%) } \\
\hline Surgical resection & $29(54)$ & $37(64)$ & $19(37)$ & $40(78)$ & $125(58)$ \\
\hline Radiotherapy & $7(13)$ & $17(29)$ & $5(10)$ & $12(24)$ & $41(19)$ \\
\hline Local treatment for HCC & $25(46)$ & $33(57)$ & $29(57)$ & $40(78)$ & $127(59)$ \\
\hline Systemic therapy & $22(41)$ & $57(98)$ & $32(63)$ & $46(90)$ & $157(73)$ \\
\hline Sorafenib & $15(28)$ & $56(97)$ & $30(59)$ & $40(78)$ & $141(66)$ \\
\hline
\end{tabular}

Reproduced with permission from Sangro B, et al. [28]

Table 4. CheckMate 040 dose-expansion cohort $(n=214)$ overall survival rates

\begin{tabular}{llllll}
\hline $\begin{array}{l}\text { Survival rate, } \\
\%(95 \% \mathrm{Cl})^{\mathrm{a}}\end{array}$ & $\begin{array}{l}\text { Uninfected: } \\
\text { sorafenib } \\
\text { naïve/ } \\
\text { intolerant } \\
(\mathrm{n}=54)\end{array}$ & $\begin{array}{l}\text { Uninfected: } \\
\text { sorafenib } \\
\text { progressors } \\
(\mathrm{n}=58)\end{array}$ & $\begin{array}{l}\text { HCV } \\
(\mathrm{n}=51)\end{array}$ & $\begin{array}{l}\text { HBV } \\
(\mathrm{n}=51)\end{array}$ & $\begin{array}{l}\text { Total } \\
(\mathrm{n}=214)\end{array}$ \\
\hline 6-Month & $\begin{array}{l}89.8(77.1,95.6) \\
75.6(61.5,85.2)\end{array}$ & $82.1(61.3,92.4)$ & $83.3(67.6,91.8)$ & $82.5(75.8,87.5)$ \\
9-Month & $79.8(50.6,92.8)$ & $\mathrm{NC}$ & $\mathrm{NC}$ & $\mathrm{NC}$ & $70.8(56.6,81.1)$ \\
\hline
\end{tabular}

aEstimated using the Kaplan-Meier method. $\mathrm{Cl}=$ confidence interval; $\mathrm{NC}=$ not calculated. Reproduced with permission from Sangro B, et al. [28]

with the anti-CTLA-4 antibody ipilimumab (cohort 4), and a study of nivolumab in ChildPugh B patients (cohort 5).

Other ongoing trials include the dose-expansion study (cohort 2), a phase III trial comparing first-line nivolumab (anti-PD-L1 antibody) with sorafenib, a phase III trial of pembrolizumab as second-line therapy after sorafenib failure, and a phase II trial of combination therapy with the anti-PD-L1 antibody durvalumab and the anti-CTLA-4 antibody tremelimumab (table 8). The results of a clinical trial of an anti-CTLA-4 antibody for the treatment of HCC were published in the Journal of Hepatology in 2013. However, the anti-CTLA-4 antibody 
Table 5. CheckMate 040 dose-escalation cohort $(n=48)$ baseline patient characteristics and prior treatment history

\begin{tabular}{|c|c|c|c|c|}
\hline & $\begin{array}{l}\text { Uninfected } \\
(\mathrm{n}=23)\end{array}$ & $\begin{array}{l}\mathrm{HCV} \\
(\mathrm{n}=10)\end{array}$ & $\begin{array}{l}\mathrm{HBV} \\
(\mathrm{n}=15)\end{array}$ & $\begin{array}{l}\text { Total } \\
(\mathrm{n}=48)\end{array}$ \\
\hline $\begin{array}{l}\text { Median age (range), years } \\
\geq 65 \text { years, } n(\%)\end{array}$ & $\begin{array}{l}61(22-79) \\
8(35)\end{array}$ & $\begin{array}{l}67(55-83) \\
6(60)\end{array}$ & $\begin{array}{l}62(41-75) \\
6(40)\end{array}$ & $\begin{array}{l}62(22-83) \\
20(42)\end{array}$ \\
\hline Male, n (\%) & $17(74)$ & $6(60)$ & $13(87)$ & $36(75)$ \\
\hline \multicolumn{5}{|l|}{ Ethnicity, n (\%) } \\
\hline White & $19(83)$ & $8(80)$ & $1(7)$ & $28(58)$ \\
\hline Asian & $2(9)$ & $2(17)$ & $14(88)$ & $18(38)$ \\
\hline Black & $2(9)$ & 0 & 0 & $2(4)$ \\
\hline Extrahepatic metastases, n (\%) & $18(78)$ & $6(60)$ & $13(87)$ & $37(77)$ \\
\hline Vascular invasion, n (\%) & $3(13)$ & $1(10)$ & $2(13)$ & $6(13)$ \\
\hline \multicolumn{5}{|l|}{ Child-Pugh score, n (\%) } \\
\hline 5 & $19(83)$ & $8(80)$ & $14(93)$ & $41(85)$ \\
\hline 6 & $4(17)$ & $2(20)$ & $1(7)$ & $7(15)$ \\
\hline$\alpha$-Fetoprotein $>200 \mu \mathrm{g} / \mathrm{L}, \mathrm{n}(\%)^{\mathrm{a}}$ & $8(35)$ & $3(30)$ & $8(53)$ & $19(40)$ \\
\hline \multicolumn{5}{|l|}{ Prior treatment type, n (\%) } \\
\hline Surgical resection & $15(65)$ & $8(80)$ & $13(87)$ & $36(75)$ \\
\hline Radiotherapy ${ }^{\mathrm{b}}$ (external or internal) & $6(26)$ & $2(20)$ & $2(13)$ & $10(21)$ \\
\hline Local treatment for $\mathrm{HCC}^{\mathrm{c}}$ & $11(48)$ & $8(80)$ & $12(80)$ & $31(65)$ \\
\hline Systemic therapy & $18(78)$ & $6(60)$ & $15(100)$ & $39(81)$ \\
\hline Sorafenib & $16(70)$ & $5(50)$ & $14(93)$ & $35(73)$ \\
\hline
\end{tabular}

aBaseline $\alpha$-fetoprotein values were missing for one uninfected patient; ${ }^{\mathrm{b} C o u l d}$ include radioembolization; 'TACE, RFA, or percutaneous ethanol injection. Reproduced with permission from El-Khoueiry AB, et al. [29]

Table 6. CheckMate 040 dose-escalation cohort $(n=48)$ TRAE

\begin{tabular}{lll}
\hline & \multicolumn{2}{l}{ Total $(\mathrm{n}=48)$} \\
\cline { 2 - 3 } & Any grade & Grade 3-4 \\
\hline Patients with any TRAE, $\mathrm{n}(\%)$ & $38(79)$ & $12(25)$ \\
Symptomatic TRAEs reported in $>5 \%$ of all patients, $\mathrm{n}(\%)$ & & \\
Rash & $11(23)$ & 0 \\
Pruritus & $7(15)$ & 0 \\
Diarrhea & $4(8)$ & 0 \\
Asthenia & $3(6)$ & 0 \\
Decreased appetite & $3(6)$ & 0 \\
Dry mouth & $3(6)$ & 0 \\
Fatigue & $3(6)$ & $1(2)$ \\
Laboratory-value TRAEs reported in $>5 \%$ of all patients, n (\%) & & \\
AST increased & $10(21)$ & $5(10)$ \\
Lipase increased & $10(21)$ & $6(13)$ \\
Amylase increased & $9(19)$ & $1(2)$ \\
ALT increased & $7(15)$ & $3(6)$ \\
Anemia & $3(6)$ & $1(2)$ \\
Hypoalbuminemia & $3(6)$ & 0 \\
Hyponatremia & $3(6)$ & 0 \\
\hline
\end{tabular}

Reproduced with permission from El-Khoueiry AB, et al. [29] 
Table 7. CheckMate 040 dose-escalation cohort $(n=48)$ investigator-assessed best overall response (RECIST v1.1)

\begin{tabular}{lllll}
\hline & $\begin{array}{l}\text { Uninfected } \\
(\mathrm{n}=23)\end{array}$ & $\begin{array}{l}\text { HCV } \\
(\mathrm{n}=10)\end{array}$ & $\begin{array}{l}\text { HBV } \\
(\mathrm{n}=15)\end{array}$ & $\begin{array}{l}\text { Total } \\
(\mathrm{n}=48)\end{array}$ \\
\hline Objective response, $\mathrm{n}(\%)$ & $3(13)$ & $3(30)$ & $1(7)$ & $7(15)$ \\
CR & $2(9)$ & $1(10)$ & 0 & $3(6)$ \\
PR & $1(4)$ & $2(20)$ & $1(7)$ & $4(8)$ \\
SD & $13(57)$ & $5(50)$ & $6(40)$ & $24(50)$ \\
PD & $6(26)$ & $2(20)$ & $7(47)$ & $15(31)$ \\
Not evaluable & $1(4)$ & 0 & $1(7)$ & $2(4)$ \\
Ongoing response, $\mathrm{n}(\%)$ & $1(33)$ & 0 & 0 & $1(14)$ \\
\hline
\end{tabular}

Reproduced with permission from El-Khoueiry AB, et al. [29]

was associated with a slightly higher rate of adverse events than the anti-PD-1 antibody [30] (table 9).

\section{Future Perspectives}

The previously described interim analysis results from the phase I/II trial for HCC (doseexpansion cohort) that were presented at ASCO 2016 involved monotherapy with anti-PD-1 antibody. The anti-PD-1 antibody nivolumab has been approved for certain malignancies, including melanoma, non-small-cell lung cancer, and kidney cancer, and is expected to yield favorable outcomes in ongoing trials for many other types of cancer [31-36]. HCC requires different treatment strategies compared with other solid tumors or hematologic malignancies because it is extremely heterogeneous, does not have any major driver mutations, and cannot be treated with drugs that reduce hepatic functional reserve. The outcomes of this phase I/II dose-expansion trial indicate that the anti-PD-1 antibody is a promising treatment for HCC.

Additionally, as mentioned in the previous section, many pharmaceutical companies have started phase III trials and other early phase clinical trials of anti-PD-1/PD-L1 antibody for the treatment of HCC, the results of which are eagerly awaited.

There are unmet needs in HCC management in various settings, including neoadjuvant or adjuvant therapy with resection or ablation, combination of anti-PD-1 antibody with transcatheter arterial chemoembolization (TACE) [37, 38], and first- and second-line treatment. The immune checkpoint-inhibiting anti-PD-1, anti-PD-L1, and anti-CTLA-4 antibodies may prove useful for adjuvant therapy or combination therapy in all these settings. Immune checkpoint inhibitors could be particularly effective for the treatment of inflammation induced by TACE or radiofrequency ablation (RFA) [39, 40], which releases highly antigenic neoantigens into the bloodstream. A clinical trial of adjuvant therapy with anti-CTLA-4 antibody after TACE and RFA is currently underway (table 9). The results of the interim analysis for that trial were presented at ASCO 2016. Adjuvant therapy with anti-CTLA-4 antibody after non-curative RFA or TACE caused an increase in CD3-positive and CD8-positive cells, even for untreated nodules [41].

A most promising topic in this area is the combination of these antibodies (anti-PD-1/ PD-L1 antibodies) with other drugs. Potential drug combinations include anti-CTLA4 antibodies (ipilimumab and tremelimumab) and molecular targeted drugs (sorafenib and oth- 


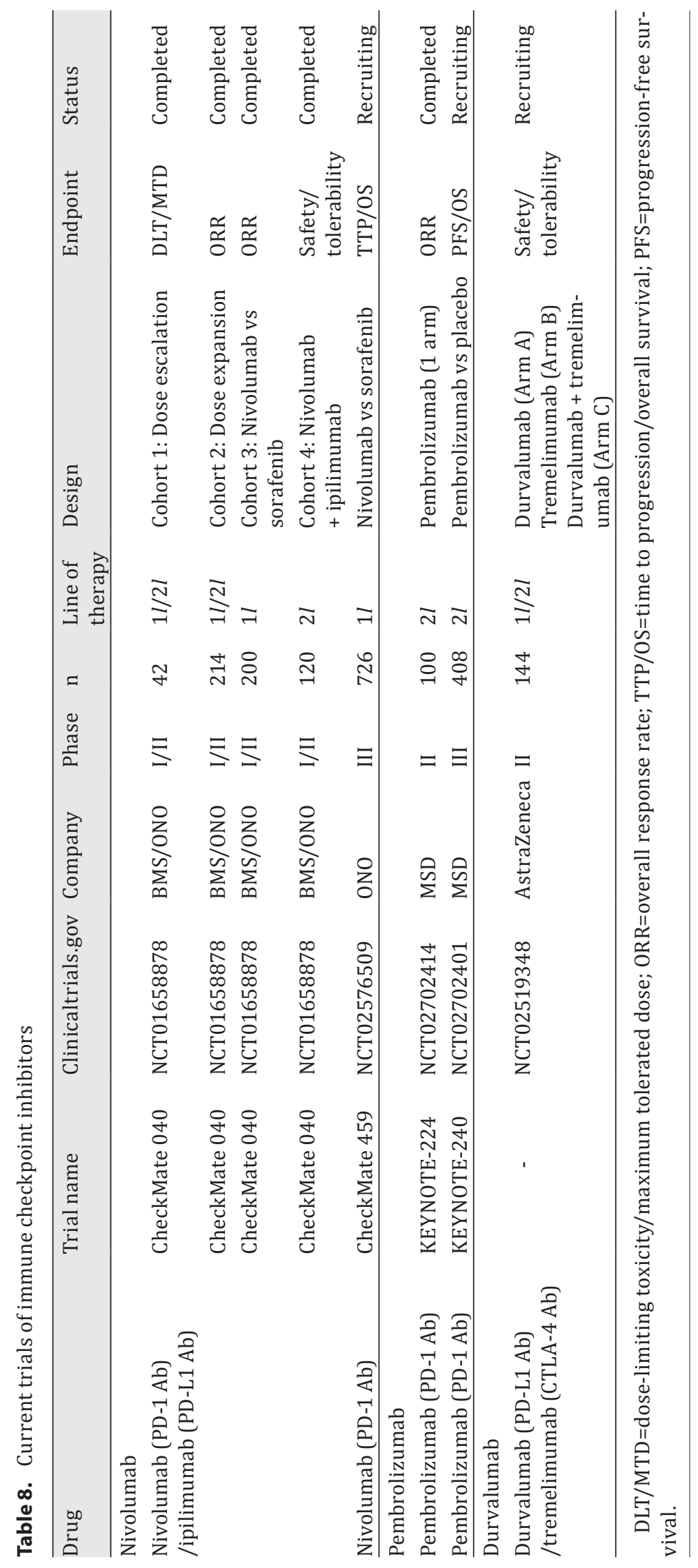


Table 9. Clinical trials of CTLA-4 antibody for the treatment of HCC

\begin{tabular}{|c|c|c|c|c|c|c|}
\hline NCT no. & Agent & Design & Status & $\mathrm{n}$ & Stage & Results \\
\hline 01008358 & Tremelimumab & II & Complete & 20 & III/IV & $\begin{array}{l}\mathrm{PR}=17.6 \%, \mathrm{DCR}=76 \% \\
\mathrm{TTP}=6.5 \text { months } \\
\text { HCV virologic response } \\
\text { Grade } 3 \text { AST } / \mathrm{ALT}=45 \%\end{array}$ \\
\hline 01853618 & $\begin{array}{l}\text { Tremelimumab + } \\
\text { TACE/RFA/ } \\
\text { cryoablation }\end{array}$ & I & Ongoing & $\begin{array}{l}29 \\
14 \text { TACE } \\
10 \text { RFA } \\
5 \text { Cryoablation }\end{array}$ & III/IV & $\begin{array}{l}\text { Safe, feasible } \\
\text { Immune cell infiltration }(+) \\
\text { TTP=5.7 month } \\
\text { Reduction in HCV viral load }\end{array}$ \\
\hline
\end{tabular}

ers). The combination of nivolumab and ipilimumab has yielded treatment outcomes superior to those of monotherapy with either drug in melanoma [31, 42].

Rapid advances in the field of immunotherapy have been made in other types of cancer. The FDA designated nivolumab as a breakthrough therapy in September 2014, and later did the same for pembrolizumab. This raised hopes that anti-PD-1 and anti-PD-L1 antibodies will be approved for the treatment of HCC in the near future. The outcomes of liver cancer treatment strategies are widely expected to improve through the application of multidrug and locoregional therapies centered on immune checkpoint inhibitors. The field is in the middle of a paradigm shift in not only systemic therapy, but also comprehensive treatment strategies, including locoregional therapy for liver cancer.

\section{Conclusion}

Having advanced through the first stage of chemotherapy centered on cytotoxic agents and the second stage of chemotherapy centered on molecular targeted therapies, we are now poised to enter a third stage of cancer treatment strategies centered on immune checkpoint inhibitors. These strategies promise to become an essential element in cancer treatment, and advances in this area will bring the paradigm shift in cancer treatment.

\section{References}

1 Ishida Y, Agata Y, Shibahara K, Honjo T: Induced expression of PD-1, a novel member of the immunoglobulin gene superfamily, upon programmed cell death. EMBO J 1992;11:3887-3895.

2 Freeman GJ, Long AJ, Iwai Y, Bourque K, Chernova T, Nishimura H, Fitz LJ, Malenkovich N, Okazaki T, Byrne MC, Horton HF, Fouser L, Carter L, Ling V, Bowman MR, Carreno BM, Collins M, Wood CR, Honjo T: Engagement of the PD-1 immunoinhibitory receptor by a novel B7 family member leads to negative regulation of lymphocyte activation. J Exp Med 2000;192:1027-1034.

3 Carter L, Fouser LA, Jussif J, Fitz L, Deng B, Wood CR, Collins M, Honjo T, Freeman GJ, Carreno BM: PD1:PD-L inhibitory pathway affects both CD4(+) and CD8(+) T cells and is overcome by IL-2. Eur J Immunol 2002;32:634-643.

4 Latchman Y, Wood CR, Chernova T, Chaudhary D, Borde M, Chernova I, Iwai Y, Long AJ, Brown JA, Nunes R, Greenfield EA, Bourque K, Boussiotis VA, Carter LL, Carreno BM, Malenkovich N, Nishimura H, Okazaki T, Honjo T, Sharpe AH, Freeman GJ: PD-L2 is a second ligand for PD-1 and inhibits T cell activation. Nat Immunol 2001;2:261-268.

5 Okazaki T, Honjo T: PD-1 and PD-1 ligands: from discovery to clinical application. Int Immunol 2007;19: 813-824.

6 Iwai Y, Ishida M, Tanaka Y, Okazaki T, Honjo T, Minato N: Involvement of PD-L1 on tumor cells in the escape from host immune system and tumor immunotherapy by PD-L1 blockade. Proc Natl Acad Sci USA 2002;99:12293-12297.

7 Krummel MF, Allison JP: CD28 and CTLA-4 have opposing effects on the response of T cells to stimulation. J Exp Med 1995;182:459-465. 
8 Leach DR, Krummel MF, Allison JP: Enhancement of antitumor immunity by CTLA-4 blockade. Science 1996;271:1734-1736.

9 Sharma P, Allison JP: The future of immune checkpoint therapy. Science 2015;348:56-61.

10 Chen DS, Mellman I: Oncology meets immunology: the cancer-immunity cycle. Immunity 2013;39:1-10.

11 Sznol M, Chen L: Antagonist antibodies to PD-1 and B7-H1 (PD-L1) in the treatment of advanced human cancer. Clin Cancer Res 2013;19:1021-1034.

12 Herbst RS, Soria JC, Kowanetz M, Fine GD, Hamid O, Gordon MS, Sosman JA, McDermott DF, Powderly JD, Gettinger SN, Kohrt HE, Horn L, Lawrence DP, Rost S, Leabman M, Xiao Y, Mokatrin A, Koeppen H, Hegde PS, Mellman I, Chen DS, Hodi FS: Predictive correlates of response to the anti-PD-L1 antibody MPDL3280A in cancer patients. Nature 2014;515:563-567.

13 Shih K, Arkenau HT, Infante JR: Clinical impact of checkpoint inhibitors as novel cancer therapies. Drugs 2014;74:1993-2013.

14 Philips GK, Atkins M: Therapeutic uses of anti-PD-1 and anti-PD-L1 antibodies. Int Immunol 2015;27:3946.

15 Mahoney KM, Freeman GJ, McDermott DF: The next immune-checkpoint Inhibitors: PD-1/PD-L1 blockade in melanoma. Clin Ther 2015;37:764-782.

16 Harshman LC, Drake CG, Wargo JA, Sharma P, Bhardwaj N: Cancer immunotherapy highlights from the 2014 ASCO Meeting. Cancer Immunol Res 2014;2:714-719.

17 Topalian SL, Drake CG, Pardoll DM: Targeting the PD-1/B7-H1(PD-L1) pathway to activate anti-tumor immunity. Curr Opin Immunol 2012;24:207-212.

18 Merelli B, Massi D, Cattaneo L, Mandalà M: Targeting the PD1/PD-L1 axis in melanoma: biological rationale, clinical challenges and opportunities. Crit Rev Oncol Hematol 2014;89:140-165.

19 Le DT, Uram JN, Wang H, Bartlett BR, Kemberling H, Eyring AD, Skora AD, Luber BS, Azad NS, Laheru D, Biedrzycki B, Donehower RC, Zaheer A, Fisher GA, Crocenzi TS, Lee JJ, Duffy SM, Goldberg RM, de la Chapelle A, Koshiji M, Bhaijee F, Huebner T, Hruban RH, Wood LD, Cuka N, Pardoll DM, Papadopoulos N, Kinzler KW, Zhou S, Cornish TC, Taube JM, Anders RA, Eshleman JR, Vogelstein B, Diaz LA Jr: PD-1 blockade in tumors with mismatch-repair deficiency. N Engl J Med 2015;372:2509-2520.

20 Droeser RA, Hirt C, Viehl CT, Frey DM, Nebiker C, Huber X, Zlobec I, Eppenberger-Castori S, Tzankov A, Rosso R, Zuber M, Muraro MG, Amicarella F, Cremonesi E, Heberer M, Iezzi G, Lugli A, Terracciano L, Sconocchia G, Oertli D, Spagnoli GC, Tornillo L: Clinical impact of programmed cell death ligand 1 expression in colorectal cancer. Eur J Cancer 2013;49:2233-2242.

21 Ribas A: Tumor immunotherapy directed at PD-1. N Engl J Med 2012;366:2517-2519.

22 Hamid O, Robert C, Daud A, Hodi FS, Hwu WJ, Kefford R, Wolchok JD, Hersey P, Joseph RW, Weber JS, Dronca R, Gangadhar TC, Patnaik A, Zarour H, Joshua AM, Gergich K, Elassaiss-Schaap J, Algazi A, Mateus C, Boasberg P, Tumeh PC, Chmielowski B, Ebbinghaus SW, Li XN, Kang SP, Ribas A: Safety and tumor responses with lambrolizumab (anti-PD-1) in melanoma. N Engl J Med 2013;369:134-144.

23 Brahmer JR, Tykodi SS, Chow LQ, Hwu WJ, Topalian SL, Hwu P, Drake CG, Camacho LH, Kauh J, Odunsi K, Pitot HC, Hamid O, Bhatia S, Martins R, Eaton K, Chen S, Salay TM, Alaparthy S, Grosso JF, Korman AJ, Parker SM, Agrawal S, Goldberg SM, Pardoll DM, Gupta A, Wigginton JM: Safety and activity of anti-PD-L1 antibody in patients with advanced cancer. N Engl J Med 2012;366:2455-2465.

24 Gao Q, Wang XY, Qiu SJ, Yamato I, Sho M, Nakajima Y, Zhou J, Li BZ, Shi YH, Xiao YS, Xu Y, Fan J: Overexpression of PD-L1 significantly associates with tumor aggressiveness and postoperative recurrence in human hepatocellular carcinoma. Clin Cancer Res 2009;15:971-979.

25 Tochio H, Sugahara M, Imai Y, Tei H, Suginoshita Y, Imawsaki N, Sasaki I, Hamada M, Minowa K, Inokuma T, Kudo M: Hyperenhanced rim surrounding liver metastatic tumors in the postvascular phase of sonazoid-enhanced ultrasonography: a histological indication of the presence of Kupffer cells. Oncology 2015;89(Suppl 2):33-41.

26 Anthony B, El-Khoueiry IM, Todd S. Crocenzi, et al: Phase I/II safety and antitumor activity of nivolumab in patients with advanced hepatocellular carcinoma (HCC): CA209-040. J Clin Oncol 2015;33(suppl; abstr LBA101)

27 Kudo M: Immune checkpoint blockade in hepatocellular carcinoma. Liver Cancer 2015;4:201-207.

28 Sangro B, et al: Safety and antitumor activity of nivolumab (nivo) in patients (pts) with advanced hepatocellular carcinoma (HCC): Interim analysis of dose-expansion cohorts from the phase 1/2 CheckMate-040 study. J Clin Oncol 2016;34 (suppl; abstr 4078)

29 El-Khoueiry AB, et al: Phase I/II safety and antitumor activity of nivolumab (nivo) in patients (pts) with advanced hepatocellular carcinoma (HCC): Interim analysis of the CheckMate-040 dose escalation study. J Clin Oncol 2016;34 (suppl; abstr 4012)l

30 Sangro B, Gomez-Martin C, de la Mata M, Iñarrairaegui M, Garralda E, Barrera P, Riezu-Boj JI, Larrea E, Alfaro C, Sarobe P, Lasarte JJ, Pérez-Gracia JL, Melero I, Prieto J: A clinical trial of CTLA-4 blockade with tremelimumab in patients with hepatocellular carcinoma and chronic hepatitis C. J Hepatol 2013;59:8188.

31 Wolchok JD, Kluger H, Callahan MK, Postow MA, Rizvi NA, Lesokhin AM, Segal NH, Ariyan CE, Gordon RA, Reed K, Burke MM, Caldwell A, Kronenberg SA, Agunwamba BU, Zhang X, Lowy I, Inzunza HD, Feely W, Horak CE, Hong Q, Korman AJ, Wigginton JM, Gupta A, Sznol M: Nivolumab plus ipilimumab in advanced melanoma. N Engl J Med 2013;369:122-133. 
32 Ansell SM, Lesokhin AM, Borrello I, Halwani A, Scott EC, Gutierrez M, Schuster SJ, Millenson MM, Cattry D, Freeman GJ, Rodig SJ, Chapuy B, Ligon AH, Zhu L, Grosso JF, Kim SY, Timmerman JM, Shipp MA, Armand P: PD-1 blockade with nivolumab in relapsed or refractory Hodgkin's lymphoma. N Engl J Med 2015;372:311-319.

33 Robert C, Schachter J, Long GV, Arance A, Grob JJ, Mortier L, Daud A, Carlino MS, McNeil C, Lotem M, Larkin J, Lorigan P, Neyns B, Blank CU, Hamid O, Mateus C, Shapira-Frommer R, Kosh M, Zhou H, Ibrahim N, Ebbinghaus S, Ribas A, KEYNOTE-006 investigators: Pembrolizumab versus ipilimumab in advanced melanoma. N Engl J Med 2015;372:2521-2532.

34 Garon EB, Rizvi NA, Hui R, Leighl N, Balmanoukian AS, Eder JP, Patnaik A, Aggarwal C, Gubens M, Horn L, Carcereny E, Ahn MJ, Felip E, Lee JS, Hellmann MD, Hamid O, Goldman JW, Soria JC, Dolled-Filhart M, Rutledge RZ, Zhang J, Lunceford JK, Rangwala R, Lubiniecki GM, Roach C, Emancipator K, Gandhi L, KEYNOTE-001 Investigators: Pembrolizumab for the treatment of non-small-cell lung cancer. N Engl J Med 2015;372:2018-2028.

35 Brahmer J, Reckamp KL, Baas P, Crinò L, Eberhardt WE, Poddubskaya E, Antonia S, Pluzanski A, Vokes EE, Holgado E, Waterhouse D, Ready N, Gainor J, Arén Frontera O, Havel L, Steins M, Garassino MC, Aerts JG, Domine M, Paz-Ares L, Reck M, Baudelet C, Harbison CT, Lestini B, Spigel DR: Nivolumab versus docetaxel in advanced squamous-cell non-small-cell lung cancer. N Engl J Med 2015;373:123-135.

36 Larkin J, Chiarion-Sileni V, Gonzalez R, Grob JJ, Cowey CL, Lao CD, Schadendorf D, Dummer R, Smylie M, Rutkowski P, Ferrucci PF, Hill A, Wagstaff J, Carlino MS, Haanen JB, Maio M, Marquez-Rodas I, McArthur GA, Ascierto PA, Long GV, Callahan MK, Postow MA, Grossmann K, Sznol M, Dreno B, Bastholt L, Yang A, Rollin LM, Horak C, Hodi FS, Wolchok JD: Combined nivolumab and ipilimumab or monotherapy in untreated melanoma. N Engl J Med 2015;373:23-34.

37 Kudo M: Locoregional therapy for hepatocellular carcinoma. Liver Cancer 2015;4:163-164.

38 Tsurusaki M, Murakami T: Surgical and locoregional therapy of HCC: TACE. Liver Cancer 2015;4:165-175.

39 Kang TW, Rhim H: Recent advances in tumor ablation for hepatocellular carcinoma. Liver Cancer 2015;4:176-187.

40 Lencioni R, de Baere T, Martin RC, Nutting CW, Narayanan G: Image-guided ablation of malignant liver tumors: recommendations for clinical validation of novel thermal and non-thermal technologies - a Western perspective. Liver Cancer 2015;4:208-214.

41 Duffy A, Makarova-Rusher OV, Pratt D, Kleiner DE, Ulahannan S, Mabry D, et al: Tremelimumab, a monoclonal antibody against CTLA-4, in combination with subtotal ablation (trans-catheter arterial chemoembolization (TACE), radiofrequency ablation (RFA) or cryoablation) in patients with hepatocellular carcinoma (HCC) and biliary tract carcinoma (BTC). J Clin Oncol 2016;34 (suppl; abstr 4073).

42 Postow MA, Chesney J, Pavlick AC, Robert C, Grossmann K, McDermott D, Linette GP, Meyer N, Giguere JK, Agarwala SS, Shaheen M, Ernstoff MS, Minor D, Salama AK, Taylor M, Ott PA, Rollin LM, Horak C, Gagnier P, Wolchok JD, Hodi FS: Nivolumab and ipilimumab versus ipilimumab in untreated melanoma. N Engl J Med 2015;372:2006-2017. 